\author{
KÁllai ERNŐ PH.D, HABIL
}

kallai@szte.jgypk.hu

főiskolai tanár (SZTE JGYPK), tudományos munkatárs (MTA TK KI)

\title{
A roma polgárjogi mozgalom személyes történet
}

\section{Personal History of the Roma Civil Rights Movement}

\author{
Horváth Aladár (2017): \\ Indulás. Roma polgárjogi mozgalom 1. \\ Wesley Kiadó. 366 oldal
}

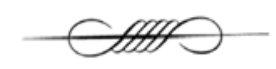

DOI 10.14232/belv.2018.3.10

https://doi.org/10.14232/belv.2018.3.10

Cikkre való hivatkozás / How to cite this article: Kállai Ernő (2018): A roma polgárjogi mozgalom személyes története. Belvedere Meridionale 30. évf. 2. sz. 156-159. pp.

ISSN 1419-0222 (print) ISSN 2064-5929 (online, pdf)

(Creative Commons) Nevezd meg! - Így add tovább! 4.0 (CC BY-SA 4.0)

(Creative Commons) Attribution-ShareAlike 4.0 International (CC BY-SA 4.0)

www.belvedere-meridionale.hu

Fontos, dokumentum értékủ könyv jelent meg nemrégiben az elmúlt évtizedek társadalom- és politikatörténete, azon belül is a roma politikai mozgalom intézményesüléseinek kezdeteiről. Az író, Horváth Aladár, a „roma mozgalom” évtizedek óta meghatározó és megkerülhetetlen „harcosa”. Az adott politikai és társadalmi viszonyoktól függően volt már tanító, parlamenti képviselő, civil jogvédő, roma aktivista és válságkezelő, miniszterelnöki tanácsadó, vagy éppen alapítványától megfosztott közéleti személyiség. A megjelent kötetben az 1990-es rendszerváltozás előtti életének alakulását, a későbbiekben pedig, ahogyan ő nevezi, a „roma polgárjogi mozgalom" történetének 1995-ig ívelő szakaszát mutatja be. 
A szerző meghatározása szerint egyfajta „,személyes történelemről” van szó, miként írja: „,... a saját szemüvegemen keresztül, egyéni látásmódom szerint ismertetem, elemzem az eseményeket... ”, és ezzel egyfajta „mikrotörténelmet” ír, de nem kutatóként, hanem az események személyes résztvevőjeként, alakítójaként, „tanúként”. Olyan ez, mint a „tények és tanúk” sorozat, ${ }^{2}$ a leírást készítő egyfajta „terepnaplót” ír résztvevő megfigyelőként, és írása még nem önmagában az elemzés, hanem inkább olyan forrásértékű dokumentum, amelyet majd a szakemberek összevetnek más írásokkal és akkor elkészül az adott téma vagy korszak tudományos elemzése.

Ez a műfaj különösen hiányzik a roma közösségek társadalomtörténeti fejlődésének feltárásából. Eddig többségében inkább interjúkötetek jelentek meg Csalog „Kilenc cigányától” a a „Kitörtőkig”, amelyekben több, közéletben is tevékenykedő, többé-kevésbé ismert vagy fontos roma személyiség életútját ismerhetjük meg. A személyes visszaemlékezésekből inkább az irodalmi stílus felé kanyarodó Péliné Nyári Hilda önéletírását ismerjük, ${ }^{5}$ vagy a már társadalomtörténeti forrásként is értkelhető Romano Rácz Sándornak a „Cigány sor” című könyvét. Romano Rácz, aki egy időben egyetemi oktatóként is dolgozott, jelentős tudást ad át nekünk az 1945 utáni magyar társadalom és abban egy cigány ember sorsáról, gyakran szakirodalmi hivatkozásokkal és elemzésekkel vegyítve élettörténetét. Ő azonban nem volt olyan típusú közszereplő, aki „történelmet csinál”. Horvát viszont igen, és bizony szükösebb lenne a tudásunk a korszak romapolitikájáról, ha nem írta volna meg könyvét.

Horváth Aladár kötete három nagy részből áll. „Az én utam” című első rész a családját és iskolás éveit mutatja be, amelyben már itt-ott megjelennek az „öntudatra ébredés” első állomásai, példaképként megjelenő roma emberek és iskolai konfliktusok formájában is. A második rész „A roma polgárjogi mozgalom születése” címet viseli, amely a rendszerváltozás előtti „miskolci gettóügy” történetét meséli el. Ez tulajdonképpen Horváth politikusi pályájának kezdete, amely országosan is ismerté tette, elvezetett a Phralipe cigány szervezet megalapításához, majd az első szabad választásokon a parlamenti képviselői mandátum elnyeréséhez. A harmadik rész, a „Magyar Országgyülés - Roma Parlament” címmel az 1990 és 1994 közötti képviselői munka eseményeit és a vele párhuzamosan megalakuló Roma Parlament első éveinek történetét taglalja, vegyítve személyes, családi történéseivel is. A kötet kiegészül dokumentum- és fényképmelléklettel is.

A visszaemlékezés egyfajta mozaikszerü leírás, amelyben keverednek a személyes, sokszor bensőséges események („Anyu Pestre költözött”) a közélet fajsúlyos kérdéseivel („Bőrfejűek támadása Egerben”). Sokszor ötletszerünek tűnik az egymás után következő részek sorrendje, de a teljes kötet elolvasásakor jól látszik, hogy ez nem csak az időrend betartása miatt van így. Megítélésem szerint egymással összefüggő, egymásra ható eseményekről olvashatunk, amelyek együtt a személyiség fejlődésének fontos állomásai. Horváth Aladár politikussá éréséhez valószínűleg hozzájárultak mindazon hatások, amelyekről a könyvben olvashatunk. Nem csak a jelentős

\footnotetext{
${ }^{1}$ Vö.: például SzíJÁRTó M. IstVÁN (1996): Mi a mikrotörténelem? Aetas 4. sz. 157-185. http://acta.bibl.u-szeged.hu/ 40762/1/aetas_1996_004_157-185.pdf.

${ }^{2}$ http://kiadok.lira.hu/kiado/magveto/index.php?action=hir\&id=1957.

${ }^{3}$ Csalog Zsolt (1976): Kilenc cigány. Budapest, Kozmosz.

${ }^{4}$ JuHÁsz Júlia (2003): Találkoztam boldoguló cigányokkal is. Budapest, Taninfo Kiadó.; SzÁle LÁszló (2009): Kitörők. Interjú tizenöt cigány értelmiségivel. Budapest, Kornétás.

${ }^{5}$ Péliné Nyári Hilda (1996): Az én kis életem. T-Twins Kiadó.

${ }^{6}$ Romano RÁcz SÁndor (2008): Cigány sor. Budapest, Osiris Kiadó Kft.
} 
személyiségekkel történő megismerkedés és tőlük való tanulás és tapasztalatszerzés, hanem az édesapjával meglévő ellentmondásos kapcsolata is hasonlóan fontosnak tűnik. Példa erre az a gyerekkori trauma, ami a gyakran italozó, szigorú apa miatt a későbbiekben is nehezen oldódott, de valószínűleg mégis egy mély tisztelet és szeretet füzte szülőjéhez a későbbi politikust, hiszen az első parlamenti belépőjének érvénytelenné válásakor a dokumentumot neki nyújtotta át, megköszönve eddigi segítségét. Hasonlóan fontos állomásként vannak jelen a roma kultúrával, kiemelten a népzenével való találkozás állomásai is a kötetben, többször is kiemelve a családi zenekar szerepét életében. Összességében tehát a lazának tűnő szerkezet egyfajta fejlődési utat vázol fel.

Érdekes módszertani megoldás a kötetben, hogy a szerző nagyon sokat idéz saját magától, azaz sokszor egykori beszédeit, parlamenti felszólalásait, újságcikkeit, interjúit közli egy-egy esemény kapcsán. Ez sok esetben nagyon jó, hiszen olyan dokumentumokat kapunk kézhez, amelyek megtalálása napjainkban már nem mindig egyszerü. Különösen így van a „miskolci gettóügy” kapcsán, ahol például a Gettóellenes Bizottság megalakulásáról készült jegyzőkönyv, vagy a korabeli Észak-Magyarország címú napilapnak az üggyel foglalkozó fontosabb cikkei is olvashatóak egy-egy fejezetben. Másrészt bizonyos esetekben hátrány is, mivel hiányérzet keletkezik az olvasóban egy például húsz évvel ezelőtt elmondott beszéd mai értelmezésének hiánya kapcsán.

Érdemes kiemelni a kötet írójának a konfliktusokat bemutató technikáját is. Itt látszik talán a legjobban a kötet személyes, visszaemlékezés jellege, és itt hiányzik leginkább egy-egy kérdés elemző, a többi szereplő szemszögéből is bemutató körbejárása. A szerző szemszögéből nézve rossz emberek és jó emberek vannak, akik keresztezték eddigi életútját a roma politikusnak, ennél árnyaltabb megközelítést nem nagyon kapunk. A „rossz emberekről”, akik „elárulták a roma mozgalmat”, nagyon keveset tudunk meg. Nem ismerjük meg nézeteiket, elképzeléseiket, inkább csak sejteni lehet, hogy milyen motívumok vezérelték őket az adott szituációban. Ugyanígy azt sem tudjuk meg, hogy például miért tartja a szerző „tudós-politikus idol”-nak, ,politikai filozófusnak" Zsigó Jenőt, és akik kevésbé jártasok a témában, bizony nehéz helyzetben vannak ilyenkor. Persze nem kérhetjük számon az elemzést ettől a műfajtól, egy visszaemlékezéstől (bár...), ezt majd elvégzik a témát kutatók. Azonban, ha lesz folytatás - amit nagyon remélünk és a szerző is tett erre már utalást - bizonyos esetekben nem térhet ki mélyebb elemzések elől, hiszen például Zsigó esetében, a legnagyobb elismerés ellenére is a későbbi időszakban bizony hosszú évekig volt „haragban” vele Horváth, és ezt majd magyaráznia kell az olvasóknak.

Az ilyen típusú, hiányolt elemzésekre azonban vannak kísérletek a kötetben, ne legyünk igazságtalanok a szerzővel. Ennek egyik jó példája „A második Kemény-féle cigányvizsgálat” címü fejezet első másfél oldala. Itt jól írja le Horvát azt a vitát, ami a roma politikusok és a tudományos kutatók között zajlott le 1993-ban. A kérdés az volt: lehet-e beleszólása a politikának a tudományos kutatásba? A roma politikusok elképzelése szerint a tartalmi és a módszertani kérdések eldöntésénél a kutatóknak a „romák hiteles képviseletével” egyeztetési kötelezettségük legyen az egyetértés eléréséig. Bár Kemény és társainak érvelését nem ismerjük meg a leírásból, csak azt, hogy határozottan elutasítottak mindenféle beleszólás lehetőségét, Horváth kifejti viszont, hogy a roma szervezetek egyetértettek a tudományos kutatás szabadságával, de a hatékonyabb érdekképviseletet és az önvédelmet tekintették a romák elsődleges társadalmi érdekének, ezért kérték a beleszólás lehetőségét. Bár ennél mélyebben nem tárgyalja a kérdést a visszaemlékezés írója - ezután a megvalósult szociológiai vizsgálat eredményeit ismerteti -, mégis nagyon fontos, 
a korszak és az akkori roma politikusok gondolkodásába avat be minket a szerző. Ha ez a fajta, elemző szemlélet a kötet többségében jelen lenne, bizony nem csak egy visszaemlékezésről és dokumentum értékü kötetről beszélhetnénk, hanem a tudományos elemzés felé elinduló írásról.

A meglévő tudományos elemzések eredményeinek használata azonban több részben is megjelenik. A roma mozgalom kialakulásának időszakáról megjelent, nem túl nagyszámú tanulmányok egy része megtalálható nem csak a kötet irodalomjegyzékében, hanem egyes részeknél használja is őket az író. Havas Gábor, Ladányi János, Neményi Mária egy-egy írása segít jobban megvilágítani az adott kor történéseit. E sorok írójának személyes megítélése szerint azonban a kötet legértékesebb részei közé azok tartoznak - különösen az első és második részben -, amikor a szerző már-már antropológiai igényü leírását adja az általa is átélt korszak társadalmának, és az akkor élt romák életkörülményeinek. A roma családok lakásviszonyai a szocialista nagyipar fellegvárában, a mindennapi élet körülményeinek leírása, olyan értékes részek, amelyek már egyetlen újságcikkből vagy tanulmányból sem rekonstruálhatóak ilyen formában napjainkban. Ha semmi másról nem szólna a kötet, mint erről, már akkor is megérte volna megírni.

Összességében elmondható: sokat hozzátett Horváth Aladár ahhoz a tudáshoz könyvével, amely a romák és a roma politika „ébredésének” időszakáról tudtunk idáig. A kép még nem teljes, nagyon jó volna, ha más akkori szereplők is fontosnak éreznék hasonló visszaemlékezések írását, mert ezek nélkül néhány évtized múlva a feledébe merülnek ezek az évek. Nagyon várjuk a kötet folytatását Horváth Aladártól is, hiszen adós maradt még a Roma Polgárjogi Alapítvány és az ő későbbi, személyes politikai tevékenységének történetével. Reméljük, elkészül majd ez is, és ezzel sokat segít a régóta remélt, a romák által megírt társadalomtörténet és saját narratíva valamikori megalkotásához. 